\title{
Effects of a Nutritive Administration of Carbohydrates and Protein by Foodstuffs on Skeletal Muscle Inflammation and Damage After Acute Endurance Exercise
}

\author{
Patrick Diel $^{1 *}$, Duc Le Viet ${ }^{1}$, Johanna Humm3,Jascha Huss ${ }^{1}$, Tasio Oderkerk ${ }^{3}$, Werner Simon ${ }^{3}$, Stephan \\ Geisler $^{2}$ \\ ${ }^{1}$ Institute for Cardiovascular Research and Sports Medicine, Department of Molecular and Cellular Sports Medicine, \\ German Sports University, Cologne, Germany
}

${ }^{2}$ Department of Fitness and Health Management, IST - University of Applied Sciences, Germany

${ }^{3}$ Rheinische Fachhochschule Cologne, Cologne, Germany

Received: May 16, 2017; Accepted: June 06, 2017; Published: June 16, 2017

*Corresponding author: Patrick Diel, PhD, Professor, German Sports University Cologne, Dept. Molecular and Cellular Sports Medicine, Am Sportpark Müngersdorf 6, 50933 Cologne, Germany, Tel: 492214982 5860; E-mail: Diel@dshs-koeln.de

\begin{abstract}
Ingestion of proteins and carbohydrates after exercise is believed to result in an enhancement of regeneration and physical performance after training. Mostly these nutrients are ingested by athletes via whey protein and glucose based shakes. In this study protein and carbohydrates were administrated via a meal. Effects of this meal delivered carbohydrate and protein ingestion directly after acute endurance exercise on skeletal muscle inflammation and damage were investigated. Therefore 16 subjects performed a $10 \mathrm{~km}$ run at $80 \%$ of the individual anaerobic threshold. After exercise subjects ingested nothing (control), white bread (carbohydrates), or white bread and sour milk cheese (carbohydrates and protein). All 16 subjects were exposed to these nutritive interventions after exercise in a cross over design. Serum glucose, serum insulin, serum Creatine Kinase (CK) as a muscle damage marker and the serum levels of the inflammation markers Interleukine 6 (IL 6) and 10 (IL 10), macrophage Migration Inhibitory Factor (MIF) and tumor necrosis factor alpha (TNF $\alpha$ ) were determined. The strongest decrease of blood glucose after exercise was observed in the protein/ carbohydrate group. Increase of serum CK measured 24 hours after exercise was significantly reduced in the protein/carbohydrate group. In the protein/carbohydrate group exercise induced increase of serum IL 6 and MIF was reduced whereas IL 10 was increased. In this group exercise increased TNF $\alpha$ concentrations in the serum could be antagonized by protein/carbohydrate ingestion. Our data indicate that uptake of protein and carbohydrate by food antagonizes the induction of serum CK, a marker of skeletal muscle damage and results in the reduction of pro inflammatory and an increase of anti-inflammatory markers in the serum. Therefore we conclude that a combined uptake of protein and carbohydrates also ingested by suitable food may reduce skeletal muscle damage after endurance exercise.
\end{abstract}

Keywords: Endurance exercise, skeletal muscle damage, Inflammation, Protein, Carbohydrates, protein shake, food

\section{Abbreviations}

ANS: Anaerobic Threshold; CK: Creatine Kinase; IL 10: Interleukine 10; IL 6: Interleukine 6; MIF: Macrophage Migration Inhibitor Factor; SD: Standard Deviations; SEM: Standard Error of the Mean; TNF $\alpha$ : Tumor Necrosis Receptor Alpha

\section{Introduction}

The uptake of proteins and carbohydrates after exercise is believed to result in an enhancement of regeneration and physical performance after training [1]. Mostly these nutrients are ingested via whey protein and glucose based shakes. Also for isolated amino acids, especially leucine, there are reports that its uptake may result in an enhancement of training effects, particularly an increase of strength [2]. Beside skeletal muscle hypertrophy, skeletal muscle recovery after exercise has been described to be influenced by protein uptake. Damage of muscle fibers by physical activity has been shown to modulate as well protein synthesis and degradation [3]. When muscle fiber degradation exceeds synthesis this results in muscle degeneration and atrophy, a reduction of muscle strength an increase of muscle soreness and impaired muscle function $[4,5]$. On the cellular level, muscle recovery after damage is related to a stimulation of protein synthesis and a reduction of protein breakdown [6]. Here it is believed that inhibition of protein breakdown is the key mechanism in the period immediately after damage recovery [7], whereas an increase of protein synthesis is most important for regeneration and hypertrophy. Therefore, all strategies affecting this balance between protein breakdown and synthesis during the period after damage, such as inhibition of inflammatory response, increased rate of protein synthesis and induction of satellite cell proliferation will enhance the regenerative processes. 
Uptake of dietary proteins has been shown to affect protein metabolism in skeletal muscle $[8,9]$. There are reports describing that whey protein supplementation results in a high availability of amino acids in the blood [10]. However data in the literature regarding the effects of protein supplementation on parameters related to muscle recovery like muscle strength, muscle soreness and CK after exercise are conflicting. There are papers demonstrating that these markers are not significantly influenced by whey protein administration after exercise [11] whereas others claim for an improvement of skeletal muscle recovery [12]. Beside uptake of proteins by shakes also commercially available sport beverages containing carbohydrate and protein are very popular. Here it is believed that the protein added to the carbohydrate drinks improves endurance performance $[13,14$, 15,16 , and 17]. Some of these drinks, if ingested immediately after exercise, are claimed to facilitate recovery. Comparing results of protein-carbohydrate combinations to the administration of carbohydrates only, combinations result in higher blood glucose levels, insulin response and glycogen storage is higher like after administration of carbohydrate only [18]. This has been taken as an indication for an improved recovery after exercise [18] after administration of such combinations. Mechanistically it is believed that insulin signaling is a key mechanism relevant for these effects. It is well known that the uptake of carbohydrates immediately after exercise results in a strong increase of serum insulin. This results in a strong decrease of blood glucose and in a stimulation of protein synthesis in the skeletal muscle induced by insulin $[19,20]$. Moreover an increase of insulin secretion results in a stimulation of amino acid uptake in skeletal muscle cells [21]. The molecular mechanism how proteins stimulate insulin secretion so far is unknown [22]. Interestingly positive effects of carbohydrate /protein combinations could also be observed after uptake of a diet containing protein and carbohydrates in a ratio of $70 \%$ to $30 \%$ [23].

In most studies addressing combinatory effects of carbohydrates and proteins on skeletal muscle regeneration carbohydrate-protein drinks were used and investigated in specifically endurance trained athletes. It was the aim of this study to investigate effects of protein carbohydrate combinations on skeletal muscle damage and inflammation in not specifically trained subjects and to use a regular food product as protein carbohydrate source. This strategy should lead to the development of concepts for increasing training effects without dietary nutritional supplements just by consuming a suitable diet consisting of regular food products in the field of health associated sport.

\section{Methods}

\section{Participants}

The study protocol according to the Declaration of Helsinki has been approved by the local ethics committee. All participants provided written informed consent prior to their participation. The study excluded subjects who were currently taking any dietary supplements, sports drinks, or functional food intended to enhance performance, or had taken any of these in the previous month. Moreover, subjects with known hypersensitivity to any of the constituents of the products under study (milk protein or lactose) were excluded. Throughout the study, subjects maintained their usual training routines and diets. All gave their written informed consent after being told about the experimental procedure. A total of 17 male participants (age: $23 \pm 3$ years; height: $181 \pm 7 \mathrm{~cm}$; weight: $76.6 \pm 9.1 \mathrm{~kg}$; mean \pm standard deviation) were recruited for the study. All were healthy and free of injury in the time period preceding the study. Participants were not specifically endurance trained but physically active sport students. Anthropomorphic characteristics of the participants are indicated in Table 1.

\begin{tabular}{|c|c|c|c|}
\hline \multicolumn{4}{|c|}{ Table 1: Antropomorphic characteristics of the participants } \\
\hline N0. & age & $\begin{array}{c}\text { Body height (in } \\
\text { cm) }\end{array}$ & $\begin{array}{c}\text { Body weight (in } \\
\text { kg) }\end{array}$ \\
\hline P 1 & 24 & 179 & 74,0 \\
\hline P 2 & 20 & 185 & 78,0 \\
\hline P 3 & 23 & 170 & 69,0 \\
\hline P 4 & 22 & 171 & 60,0 \\
\hline P 5 & 23 & 190 & 93,0 \\
\hline P 6 & 20 & 181 & 78,0 \\
\hline P 7 & 26 & 178 & 89,0 \\
\hline P 8 & 22 & 179 & 80,0 \\
\hline P 9 & 20 & 196 & 85,0 \\
\hline P 10 & 25 & 182 & 78,0 \\
\hline P 11 & 22 & 170 & 63,0 \\
\hline P 13 & 22 & 181 & 74,6 \\
\hline P 15 & 24 & 180 & 75,0 \\
\hline P 16 & 20 & 190 & 88,0 \\
\hline P 17 & 24 & 183 & 73,0 \\
\hline P 18 & 24 & 182 & 63,0 \\
\hline P 19 & 31 & 185 & 82,0 \\
\hline N = 17 & $\varnothing 23 \pm 3$ & $\varnothing 181 \pm 7$ & $\varnothing 76,6 \pm 9,1$ \\
\hline & & & \\
\hline
\end{tabular}

\section{Experimental procedure}

The aim of this study was to investigate the beneficial effects of a co-ingestion of carbohydrate and protein from a traditional food source in amateur sportsmen. For this purpose 16 non-specific endurance trained male subjects performed a $10 \mathrm{~km}$ run with intensity at $80 \%$ of individual Anaerobic Threshold (ANS). Before running, individuals were randomly divided into one of the three intervention groups. Each individual participated in every intervention group in a cross over design. Between the respective interventions there was a minimum wash out period of two weeks. One hour before exercise the fasted participants were served a defined small breakfast composition is indicated in Table 2. Immediately after exercise subjects ingest either nothing (control), carbohydrates (73 g) by eating $152 \mathrm{~g}$ white bread, or a combination of carbohydrates 
(36, $6 \mathrm{~g}$ bread) by eating $76 \mathrm{~g}$ white bread and protein $(36,1 \mathrm{~g}$ ) by eating $100 \mathrm{~g}$ of a sour milk cheese high in protein but very low in fat (Loose GmbH, Leppersdorf, Germany) . Nutrition facts of the used food products in the respective interventions are shown in Table 3. Carbohydrate and Carbohydrate/Protein intervention were nearly iso caloric (Table 3). Blood samples were taken at different time points before and after exercise and food uptake. The experimental design of the experimental procedure is shown in Figure 1.

Table 2: Compositions and calories of the given breakfast

\begin{tabular}{|c|c|c|c|c|}
\hline & $\begin{array}{c}\text { Carbohydrates } \\
\text { [g] }\end{array}$ & $\begin{array}{c}\text { Protein } \\
\text { [g] }\end{array}$ & $\begin{array}{c}\text { Fat } \\
\text { [g] }\end{array}$ & $\begin{array}{c}\text { Calories } \\
\text { [kcal] }\end{array}$ \\
\hline 30 g Cornflakes & 25,2 & 2,1 & 0,3 & 111,9 \\
\hline $\begin{array}{c}250 \text { ml milk }(1,5 \\
\% \text { fat })\end{array}$ & 12 & 8,5 & 3,8 & 116,2 \\
\hline $\begin{array}{c}\text { One banana } \\
\text { Sum }\end{array}$ & 27,4 & 1,3 & 0,4 & 118,4 \\
\hline & 64,6 & 11,9 & 4,5 & 346,5 \\
\hline
\end{tabular}

Table 3: Compositions and calories of protein and protein/carbohydrate intervention

\begin{tabular}{|c|c|c|c|c|c|}
\hline & food & $\begin{array}{c}\text { Carbohydrates } \\
\text { [g] }\end{array}$ & $\begin{array}{c}\text { Protein } \\
\text { [g] }\end{array}$ & $\begin{array}{c}\text { Fat } \\
\text { [g] }\end{array}$ & $\begin{array}{c}\text { Calories } \\
\text { [kcal] }\end{array}$ \\
\hline $\begin{array}{c}\text { Protein/ } \\
\text { Carbohydrate } \\
\text { intervention }\end{array}$ & $\begin{array}{l}\text { bread } \\
\text { and 100g } \\
\text { sour milk } \\
\text { cheese }\end{array}$ & 36,6 & 36,1 & 2,28 & 316,2 \\
\hline $\begin{array}{c}\text { Carbohydrate } \\
\text { intervention }\end{array}$ & $\begin{array}{l}\text { g white } \\
\text { bread }\end{array}$ & 73 & 12,2 & 4,46 & 382,2 \\
\hline
\end{tabular}

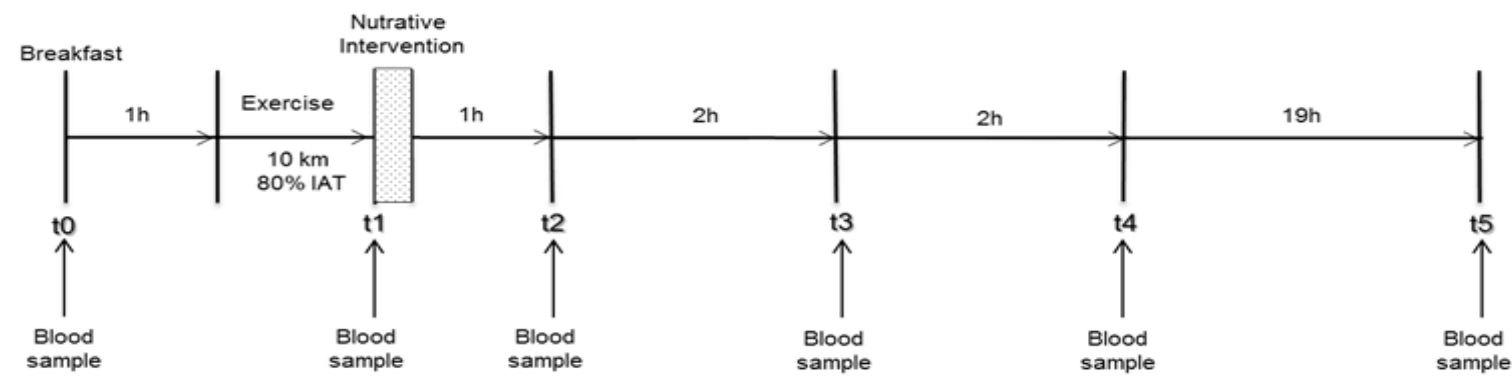

Figure 1:Experimental design of the study

\section{Measurements}

Determination of serum glucose and serum insulin: Blood glucose concentrations were determined using the Cobas Mira Plus system (Guder Medizintechnik GmbH \& Co.KG, Bad Oeynhausen, Germany). Blood insulin concentrations were determined by an external laboratory using a specific ELISA (Labor Dr. Wisplinghoff, Classen-31 Kappelmann-Straße 24, in 50931 Köln)

Creatine kinase activity: Creatine kinase activity (CK) was determined using the NADPH coupled assay following the protocol supplied by the manufacturer (ABX Pentra CK NAC CP Nr. A11A01632 and the diagnostical device ABX Pentra (Horiba ABX, Montpellier, France). Results are expressed as Units ( $\mu$ moles per minute) of NADPH formed per $\mu \mathrm{g} /$ total protein content of the homogenate of DNA, and are means \pm SEM from duplicates of three independent experiments.

\section{Serum cytokine levels}

TNF $\alpha$, IL-6, IL-10 and MIF concentrations of serum samples were analyzed using enzyme linked immunosorbent assays ac- cording to manufacturer's protocol (R\&D systems, Minneapolis, MN, USA). Values below detection thresholds were considered as threshold values for analysis.

\section{Statistical analyses}

Quantitative variables were presented as mean values and Standard Deviations (SD). Because we compared repeated measurements in which the population could not be assumed to be normally distributed we tested statistical significance using a Wilcoxon signed-rank test and the Graph Pad PRISM software (Graph Pad Software, Inc. La Jolla, USA) P < 0.05 was taken as the level of statistical significance for all procedures.

\section{Results}

\section{Effects of exercise and protein/carbohydrate on blood glucose and insulin levels}

The consumption of protein/ carbohydrate combinations after exercise has been shown to influence blood glucose and insulin response which is discussed to improve recovery. 
Therefore blood glucose levels and insulin levels were measured in our study at the time points $\mathrm{t} 0, \mathrm{t} 1, \mathrm{t} 2 \mathrm{t} 3$ and $\mathrm{t} 4$ (Figure 1 ). In Figure 2 it is visible that exercise results in a significant increase of blood glucose concentration in all groups (t1). $1 \mathrm{~h}$ after exercise and uptake of nutrients (t2) mean blood sugar levels are significantly lower in the bread/cheese group than in the bread or the control group (Figure $2 \mathrm{~A}$ ).This effect is also visible when the individuals are displayed separately (Figure 2B)

Blood insulin levels are significant higher in the bread and bread/cheese group compared to the control group $1 \mathrm{~h}$ after exercise (t2) (Figure 2C). This effect is also visible when the individuals are displayed separately (Figure 2D)

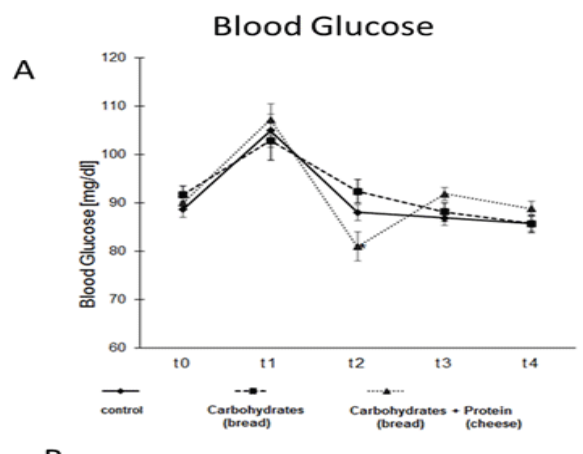

B
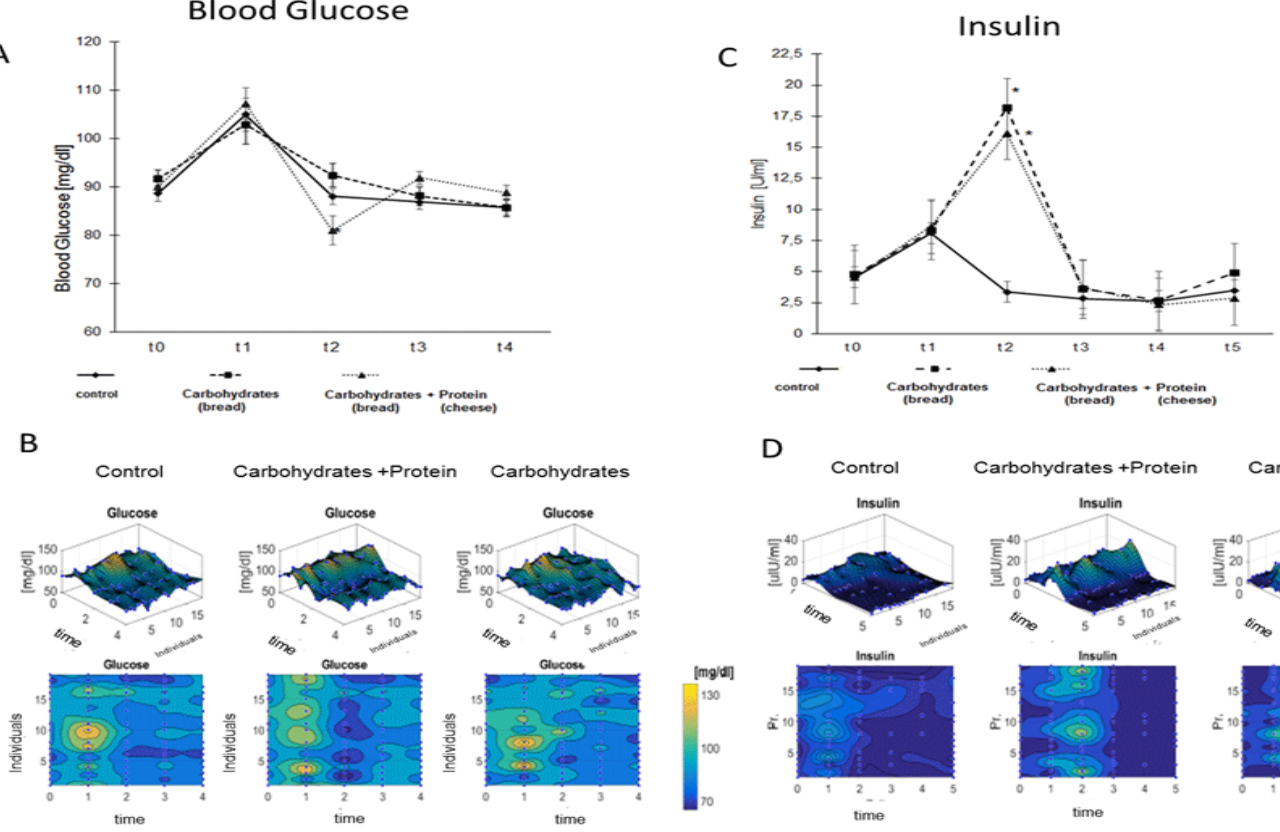

D
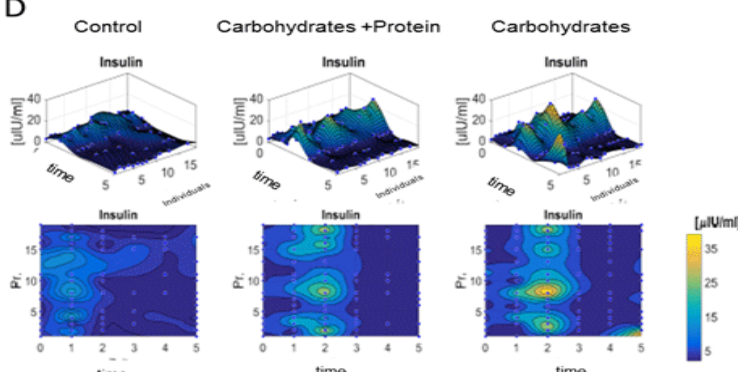

Figure 2 : Effects of protein and protein/carbohydrate uptake via food, immediately after exercise, on serum glucose and serum insulin levels. A. Mean serum blood glucose concentrations of all 16 participants. Shown is show mean \pm SD. ${ }^{*}=p \leq 0.01$ show statistically significant differences between marked group and respective t0 value. B. Individual blood glucose concentrations of the respective participants shown as $3 \mathrm{~d}$ and $2 \mathrm{~d}$ plot. C. Mean and SD of serum insulin concentrations of all 16 participants (Mean $\pm \mathrm{SD}$ ). ${ }^{*}=\mathrm{p} \leq 0.01$ show statistically significant differences between marked group and respective t0 value. D. Individual blood insulin concentrations of the respective participants shown as $3 \mathrm{~d}$ and $2 \mathrm{~d}$ plot

\section{Effects of exercise and protein/carbohydrate on blood creatine kinase levels}

Creatine kinase (CK) is a marker for skeletal muscle damage and regeneration. Therefore CK blood concentrations are measured before and $24 \mathrm{~h}$ after exercise in each intervention group. Figure $3 \mathrm{~A}$ shows the mean relative CK concentrations of all individuals in the different intervention groups setting t0 as one. Exercise results in the control and in the bread group in a significant increase of CK in the blood $24 \mathrm{~h}$ after exercise. In the bread/cheese group a lower and statistically not significant increase was detected. Figure $3 \mathrm{~B}$ displays the CK levels of the individuals at the time points $\mathrm{t} 0, \mathrm{t} 1, \mathrm{t} 2, \mathrm{t} 3, \mathrm{t} 4$ and $\mathrm{t} 5$. Comparing intensities at $\mathrm{t} 5$ it is visible that most individuals have lowest CK serum concentrations at $\mathrm{t} 5$ after the bread/cheese intervention. kine 6 (IL 6), Interleukine 10 (IL 10), Macrophage Migration Inhibitory Factor (MIF) and tumor necrosis factor alpha (TNF $\alpha$ ) in the serum. Analysis was done at the time point's t0 and $3 \mathrm{~h}$ after exercise (t3) in the control group and the bread/cheese group.

IL 6 serum levels were induced by exercise significantly (Figure 4a). No significant differences could be observed between the control and the bread/cheese group. Il10 serum levels were significantly increased in the bread/cheese group after exercise, but not in the control group (Figure $4 \mathrm{~b}$ ). MIF serum levels were significantly increased in the control group after exercise, but not in the bread/cheese group (Figure 4c) TNF alpha serum levels were significantly decreased in the control group after exercise, but not in the bread/cheese group (Figure 4d).

\section{Effects of exercise and protein/carbohydrate on markers of inflammation}

Skeletal muscle damage results in an induction of inflammation. To analyze whether the protective effects after protein / carbohydrate uptake observed for CK are also reflected by the response of markers for inflammation we measured Interleu- 
A

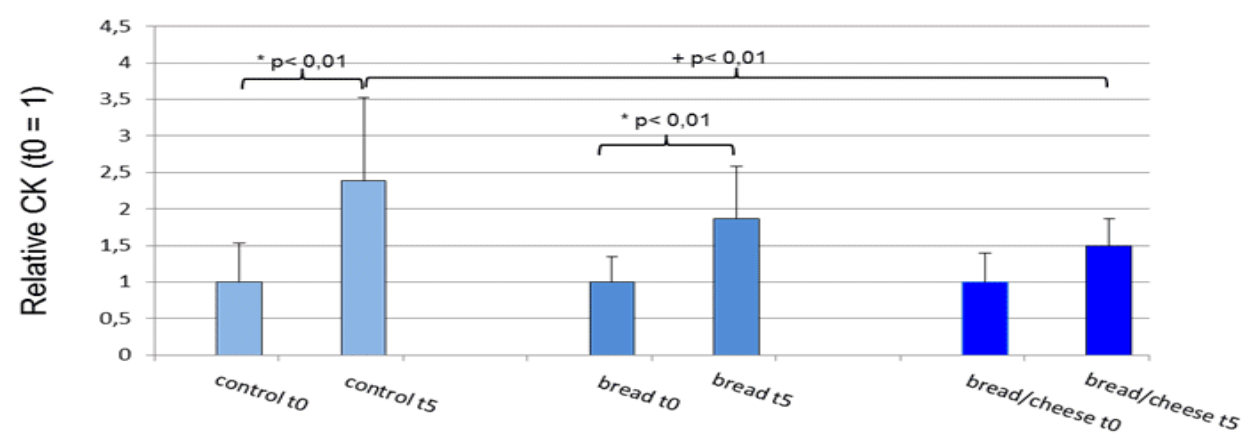

B
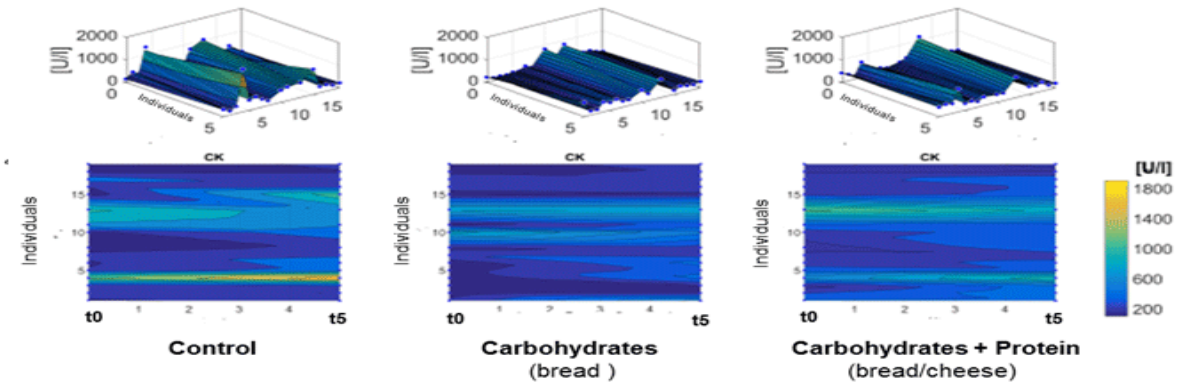

Figure 3 :Effects of protein and protein/carbohydrate uptake via food, immediately after exercise, on serum CK levels $24 \mathrm{~h}$ after exercise. A. Changes in relative CK. Here for normalization the individual CK at $\mathrm{t} 0$ was set to 1 and change calculated in \% increase. Shown is mean of all individuals \pm SD. ${ }^{*}$ $=\mathrm{p} \leq 0.01$ show statistically significant differences between marked group and respective t0 value. B. Individual changes of the respective participants shown as $3 \mathrm{~d}$ and $2 \mathrm{~d}$ plot.
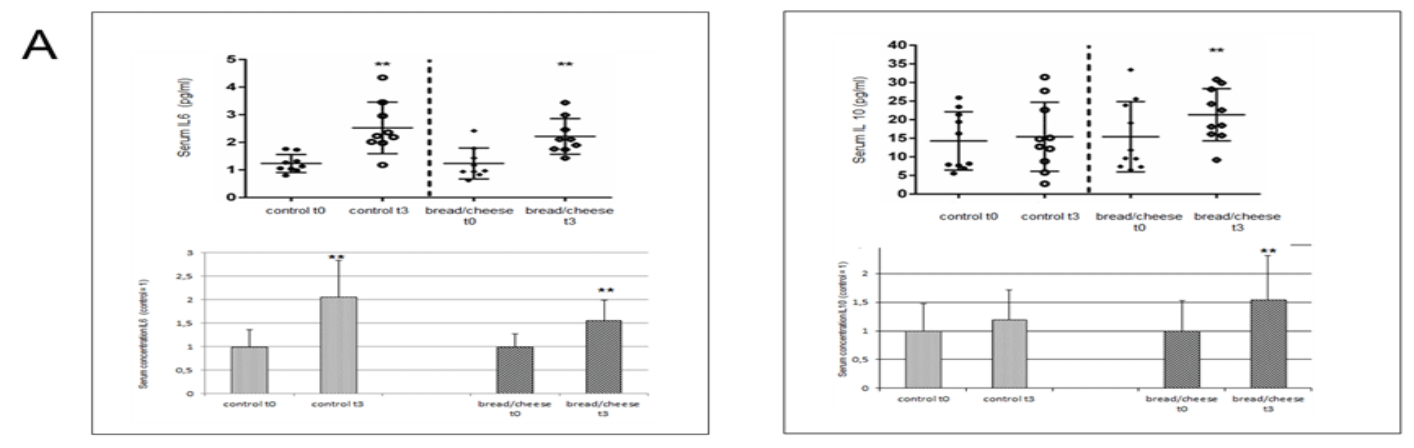

B
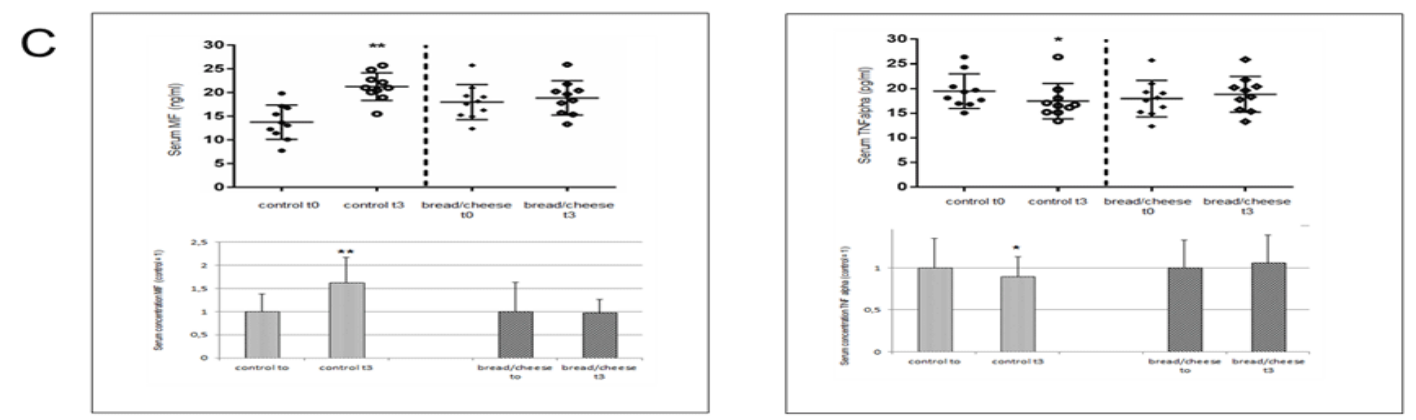

Figure 4 :Effects of protein and protein/carbohydrate uptake via food, immediately after exercise, on serum levels of IL 6 (A) IL 10 (B), MIF (C) and TNF $\alpha$ (D) $3 \mathrm{~h}$ after exercise. Shown are individual absolute serum concentrations of the respective cytokines (upper graph) and changes in the relative serum concentrations (lower graph). Here serum concentration of the individuals at t0 was set 1 and changes of t 3 were calculated in \%. Shown is mean \pm SD. ${ }^{*}=p \leq 0.01,{ }^{* *}=p \leq 0.001$ statistically significant differences between marked group and respective t0 value. 


\section{Discussion}

In the present study we examined the effects of a dietary uptake of protein and carbohydrates after endurance exercise on skeletal muscle recovery and damage. Here specific emphasis was given to the question whether ingestion of protein and carbohydrates by food may result in comparable beneficial effects as already described for consuming of carbohydrate/protein beverages.

The main findings of our study are:

A.) Ingestion of a protein and carbohydrate combination by food after endurance exercise, results in a significant decrease of blood sugar levels $1 \mathrm{~h}$ after exercise compared to t0 measurements. This effect could not be observed in the groups ingest nothing or only carbohydrates.

B.) Ingestion of protein and carbohydrate immediately after exercise by food reduces circulating CK serum levels significantly; indicating a reduced skeletal muscle damage and increased recovery.

C.) Ingestion of protein and carbohydrate immediately after exercise by food reduces circulating levels of the pro inflammatory cytokines IL 6 and MIF, but increases the levels of the anti inflammatory cytokine IL10. This pattern clearly indicates a suppression of inflammation by the food ingestion.

Effects of ingestion of protein/carbohydrate combination's after endurance exercise on of skeletal muscle damage and recovery have been described in the literature and mechanistically linked to a stimulation of insulin secretion [17]. Therefore in this study we have monitored blood glucose levels and also insulin levels at different time points after exercise and protein carbohydrate ingestion. In Figure 2A it is clearly visible that exercise results in an increase of blood glucose levels ( $\mathrm{t} 1$ ). This is in line with observations that moderate-intensity exercise normally improves blood glucose in healthy no diabetic persons when a required exercise volume is achieved [24]. Analyzing blood sugar levels at $\mathrm{t} 2$ in the carbohydrate/protein group shows an interesting result. Even the insulin levels between the carbohydrate and carbohydrate/protein group are not significantly different at t2, blood sugar levels at $\mathrm{t} 2$ are significantly lower than in the carbohydrate or the control group. This can be taken as an indication, that after exercise and food uptake the circulating insulin levels in the protein/carbohydrate group must have been higher than in the other groups. It will be necessary in future studies to determine insulin levels at multiple time points in the first $60 \mathrm{~min}$ after food ingestion. However this interpretation is in line with published data showing that protein/carbohydrate beverages increase insulin levels stronger then carbohydrate beverages [13, 17].

Our main physiological endpoint investigated in this study was skeletal muscle damage and recovery after exercise. Therefore we measured creatine kinase in the serum as a parameter related to skeletal muscle damage and recovery [25]. Combinations of proteins/carbohydrates ingested before, after, or during endurance exercise have been our main physiological endpoint investigated in this study was skeletal muscle damage and recovery after exercise. Therefore we measured creatine kinase in the serum as a parameter related to skeletal muscle damage and recovery [25]. Combinations of proteins/carbohydrates ingested before, after, or during endurance exercise have been shown to result in lowered post exercise muscle soreness [26] and lower plasma concentrations of both myoglobin [27] and CK [28]. For these reasons we also measured CK in serum in the respective groups and individuals at different time points after exercise (Figure $3 \mathrm{~B}$ ). As visible in Figure $3 \mathrm{~A}$, a statistically significant increase in mean circulation serum $\mathrm{CK}, 24 \mathrm{~h}$ after exercise ( $\mathrm{t} 5$ ) is detectable in the control group and in the carbohydrate group, but not in the protein/carbohydrate combination group. This can be taken as an indication that skeletal muscle damage, induced by exercise is lower after uptake of protein/carbohydrate in combination and is in line with previously described results [11]. However in our experimental design, administration of protein and carbohydrate was via ingestion a meal composed of white bread and sour milk cheese. Therefore our results demonstrate that skeletal muscle regeneration after exercise can be stimulated not only by the ingestion of protein/carbohydrate beverages. Ingestion by food also seems to be effective. This hypothesis is further supported by our data regarding the effects of carbohydrate/protein combinations on serum markers for inflammation. It is known that acute exercise induces in an inflammatory response in the skeletal muscle resulting in an increase of the expression of proinflammatory cytokines and followed by an anti-inflammatory reaction $[29,30]$. Strenuous exercise results in increased levels in a number of pro-inflammatory and anti-inflammatory cytokines like TNF $\alpha$, IL-1, IL-6, IL-1 receptor antagonist, TNF receptors, IL10 , IL-8 and macrophage inflammatory protein-1 [30]. Increase of pro and anti-inflammatory cytokines has been also described in animal models were skeletal muscle damage is induced by notoxin [31]. For these reasons we investigated the circulating levels of the pro inflammatory cytokines IL 6, TNF $\alpha$ and MIF and the anti-inflammatory cytokine IL10, 3h after exercise (t3) in the control and in the protein /carbohydrate group. Like shown in Figure 4 the serum levels of the pro inflammatory cytokines Il6 and MIF were induced by exercise significantly in the control but not in the protein/carbohydrate group. In contrast the serum levels of the anti-inflammatory cytokine IL10 was only induced after exercise in the protein/carbohydrate group but not in the control group. These regulation patterns demonstrate that administration of protein/carbohydrate after exercise suppresses the excretion of proinflammatory cytocines but increases the excretion of antiinflammatory proteins in the serum which can be interpreted as an anti-inflammatory effect. Indeed in an animal model where muscle damage was ced by administration of notoxin accelerated skeletal muscle regeneration was correlated with an increased IL10 expression and a decreased TNF $\alpha$ expression in the respective skeleton muscles [31].

\section{Conclusion}

Our data demonstrate that uptake of a combination of protein and carbohydrate by a meal immediately after endurance exercise effects physiological responses like blood glucose and insulin levels of the individuals. Uptake of protein and carbohydrate also antagonize the induction of serum CK, a marker of skeletal muscle damage. Moreover this nutritive carbohydrate/protein 
uptake seems to influence the inflammatory response of the skeletal muscle indicated by reduced concentrations of pro inflammatory markers and an increase of anti-inflammatory markers.

Therefore a combined uptake of protein and carbohydrates appears to reduce skeletal muscle damage after endurance exercise, most likely via a modulation of the immune response of the skeletal muscle. Our data also provide evidence that mechanistically insulin may be involved in initiation and mediation of the pro-regenerative effects. All these beneficial effects can be achieved just by the ingestion of a meal containing sufficient concentrations of carbohydrates and protein. This finding is of relevance for developing concepts to support training by a suitable diet without the need to consume nutrition supplements or isolated proteins.

\section{References}

1. Maughan RJ, Depiesse F, Geyer H, International Association of Athletics Federations. The use of dietary supplements by athletes. International Association of Athletics Federations. J Sports Sci. 2007;25 Suppl 1:103-113

2. Reidy PT, Rasmussen BB. Role of Ingested amino acids and protein in the promotion of resistance exercise-induced muscle protein anabolism. J Nutr. 2016;146(2):155-183. doi: 10.3945/jn.114.203208

3. Bonaldo P, Sandri M. Cellular and molecular mechanisms of muscle atrophy. Disease Models and Mechanisms. 2013;6(1):25-39. doi: 10.1242/dmm.010389

4. Armstrong RB, Warren GL, Warren JA. Mechanisms of exercise-induced muscle fibre injury. Sports Med. 1991;12(3):184-207.

5. Trappe TA, White F, Lambert CP, Cesar D, Hellerstein M, Evans WJ. Effect of ibuprofen and acetaminophen on postexercise muscle protein synthesis. American Journal of Physiology -Endocrinology and Metabolism. 2002;282; 551-556.

6. Koopman R, Wagenmakers AJ, Manders RJ, Zorenc AH, Senden JM, Gorselink M, et al. Combined ingestion of protein and free leucine with carbohydrate increases postexercise muscle protein synthesis in vivo in male subjects. Am J Physiol Endocrinol Metab. 2005;288(4):E645653.

7. Sandri M. Signaling in Muscle Atrophy and Hypertrophy. Physiology. 2008;23:160-170. doi: 10.1152/physiol.00041.2007

8. Tang JE, Moore DR, Kujbida GW, Tarnopolsky MA, Phillips SM. Ingestion of whey hydrolysate, casein, or soy protein isolate: effects on mixed muscle protein synthesis at rest and following resistance exercise in young men. J Appl Physiol. 2009;107(3):987-992. doi: 10.1152/japplphysiol.00076.2009

9. Symons TB, Sheffield-Moore M, Wolfe RR, Paddon-Jones D. A moderate serving of high-quality protein maximally stimulates skeletal muscle protein synthesis in young and elderly subjects. J Am Diet Assoc. 2009;109(9):1582-1586.

10. Markus CR, Olivier B, de Haan EH. Whey protein rich in $\alpha$-lactalbumin increases the ratio of plasma tryptophan to the sum of the other large neutral amino acids and improves cognitive performance in stressvulnerable subjects. Am J Clin Nutr. 2002;75(6):1051-1056.

11. White JP, Wilson JM, Austin KG, Greer BK, St John N, Panton LB. Effect of carbohydrate-protein supplement timing on acute exerciseinduced muscle damage. J Int Soc Sports Nutr. 2008;19(5):5. doi: 10.1186/1550-2783-5-5

12 Buckley JD, Thomson RL, Coates AM, Howe PR, Denichilo MO, Rowney MK. Supplementation with a whey protein hydrolysate enhances recovery of muscle force-generating capacity following eccentric exercise. J Sci Med Sport. 2010;13(1):178-181. doi: 10.1016/j. jsams.2008.06.007
13 Manninen AH. Hyperinsulinaemia, hyperaminoacidaemia and postexercise exercise: influence on performance and recovery. Int J of Sport Nutr and Exe Met. 2006;17:87-103.

14 Saunders MJ, Kane MD, Todd MK. Effects of a carbohydrate-protein beverage on cycling endurance and muscle damage. Med Sci Sports Exerc. 2004;36(7):1233-1238.

15. Kerksick C, HarveyT, Stout J, Campbell B, Wilborn C, Kreider R, et al. International Society of Sports Nutrition position stand: nutrient timing. J Int Soc Sports Nutr. 2008;5:17. doi: 10.1186/1550-2783-5-17

16 Valentine RJ, Saunders MJ, Todd MK, Laurent TG. Influence of carbohydrate-protein beverage on cycling endurance and indices of muscle disruption. Int J Sport Nutr Exerc Metab. 2008;18(4):363-378.

17. Hill KM, Stathis CG, Grinfeld E, Hayes A, McAinch AJ. Co-ingestion of carbohydrate and whey protein isolates enhance PGC- $1 \alpha$ mRNA expression: a randomised, single blind, cross over study. J Int Soc Sports Nutr. 2013;10(1):8. doi: 10.1186/1550-2783-10-8

18. Van Loon LJ, Saris WH, Verhagen H, Wagenmakers AJ. Plasma insulin responses after ingestion of different amino acid or protein mixtures with carbohydrate. Am J Clin Nutr. 2000;72(1):96-105.

19 Anthony JC, Lang CH, Crozier SJ, Anthony TG, MacLean DA, Kimball $\mathrm{SR}$, et al. Contribution of insulin to the translational control of protein synthesis in skeletal muscle by leucine. Am J Physiol Endocrinol Metab. 2002;282(5): E1092-1101.

20 Fujita S, Rasmussen BB, Cadenas JG, Grady JJ, Volpi E. Effect of insulin on human skeletal muscle protein synthesis is modulated by insulininduced changes in muscle blood flow and amino acid availability. Am J Physiol Endocrinol Metab. 2006;291(4):E745-754.

21 Bonadonna R, Saccomani m, Cobelli C, DeFronzo R. Effect of insulin on system A amino acid transport in human skeletal muscle. J Clin Invest. 1993;91(2):514-521.

22 Behrends C, Sowa ME, Gygi SP, Harper JW. Network organization of the human autophagy system. Nature. 2010;466(7302):68-76. doi: $10.1038 /$ nature09204

23 Ivy JL, Goforth HW Jr, Damon BM, McCauley TR, Parsons EC, Price TB. Early postexercise muscle glycogen recovery is enhanced with a carbohydrate-protein supplement. J Appl Physiol. 2002;93(4):13371344.

24 Adams P. The impact of brief high-intensity exercise on blood glucose levels. Diabetes Metab Syndr Obes. 2013;6:113-122. doi: 10.2147/ DMSO.S29222

25. Candow DG, Chilibeck PD, Facci M, Abeysekara S, Zello GA. Protein supplementation before and after resistance training in older men. Eur J Appl Physiol. 2006;97(5):548-556.

26 Millard-Stafford M, Warren GL, Thomas LM, Doyle JA, Snow T, Hitchcock K. Recovery from run training: efficacy of a carbohydrate-protein beverage? Int J Sport Nutr Exerc Metab. 2005;15(6):610-624.

27 Seifert JG, Kipp RW, Amann M, Gazal O. Muscle damage, fluid ingestion, and energy supplementation during recreational alpine skiing. Int J Sport Nutr Exerc Metab. 2005;15(5):528-536.

28 Saunders MJ. Coingestion of carbohydrate-protein during endurance muscle anabolism: the search for the optimal recovery drink. British Journal of Sports Medicine. 2007;40(11):900-905.

29 Walsh NP, Gleeson M, Pyne DB, Nieman DC, Dhabhar FS,Shephard RJ, et al. Position statement. Part two: maintaining immune health. Exerc ImmunolRev. 2011;17:64-103

30 Petersen AM, Pedersen BK. The role of IL-6 in mediating the antiinflammatory effects of exercise. J PhysiolPharmacol 2006;57 Suppl 10:43-51.

31 Velders M, Schleipen B, Fritzemeier KH, Zierau O, Diel P. Selective estrogen receptor- $\beta$ activation stimulates skeletal muscle growth and regeneration. FASEB J. 2012;26(5):1909-1920. doi: 10.1096/fj.11194779 